\title{
Using of autochthonous grape varieties in the production of sparkling wines
}

\author{
Alexander Makarov *, Igor Lutkov, Natalia Shmigelskaya, Victoria Maksimovskaia, and \\ Galina Sivochoub
}

Federal State Budget Scientific Institution All-Russian National Research Institute of Viticulture and Winemaking Magarach of the RAS, 298600, Yalta, Republic of Crimea, Russian Federation

\begin{abstract}
In order to increase the production of original and recognizable sparkling wines, base wines from autochthonous grape varieties can be used for their preparation. Based on the studied basic and advanced physicochemical and organoleptic characteristics, it was concluded about the possibility of using autochthonous grape varieties - 'Makhrovatchic', 'Tsimlyanskii Belyi', 'Tsimladar', 'Kefesiya', 'Kokur Krasnyi' and 'Chernyi Krymskii' - for production of high-quality sparkling wines. The relationships of the phenolic complex components with the parameters of sparkling wines, characterizing their appearance, was established, so for white sparkling wines - mass concentration of polymeric forms of phenolic substances with yellowness index $(r=0.925)$; for red ones - mass concentration of monomeric forms of phenolic compounds and mass concentration of coloring agents with the index of color intensity $r=0.580$ and $\mathrm{r}=0.786$, respectively; for white and red sparkling wines - mass concentration of polymeric forms of phenolic substances with a maximum foam volume $(\mathrm{r}=0.628)$. It was also noted as a positive factor that all samples accumulated a sufficient amount of the bound $\mathrm{CO}_{2}$ (not less than $8 \%$ of the total bottle content.
\end{abstract}

\section{Introduction}

One of trends of the modern wine market is an increase in demand for original products, associated with the area of wine production. These products include the so-called "terroir" wines, which flavor and aroma are unique and recognizable. Products made of local autochthonous grape varieties are especially appreciated. Still wine Serrapetrona and red sparkling Vernaccia di Serrapetrona are produced in Italy from local variety 'Vernaccia Nera' [1]. In Greece, local autochthonous grape varieties with muscat aroma are widely used for wine production [2]. Local autochthonous varieties 'Tosote' and 'Kokhpeni' are used for production of high-quality red wines in Armenia [3]. Spain produces sparkling wines from local grape varieties 'Albarín', 'Verdejo', 'Godello' and 'Prieto Picudo' [4]. In Georgia, 525 autochthonous grape varieties, suitable for wine production, are known [5]. In Crimea, the famous red liqueur wine Chernyi Doctor is produced from local grape varieties ('Ekim Kara' and 'Kefesiya'). Crimean sparkling wine, produced from 'Kokur Belyi' grape

\footnotetext{
*Corresponding author:: makarov150@rambler.ru
} 
variety is already recognized at international exhibitions and trade-shows. The Institute Magarach Ampelographic Collection [6,7] contains 84 local grape varieties. Some of them are drought or frost resistant [8]. A number of works of the Institute Magarach [9-12] is concerned with the research of local grape varieties, in particular, the composition of phenolic complex of grapes and base wines. Studies on productibility of local grape varieties for preparation of high-quality base wines for white and red sparklings were carried out in the Laboratory of Sparkling Wines of the Institute Magarach [13-15], however the quality of the finished product is understudied yet. The aim of the work was to study the possibility of using autochthonous grape varieties for the preparation of highquality sparkling wines.

\section{Materials and methods}

The objects of research were sparkling wines made of white and red Crimean and Don autochthonous grape varieties grown in the Institute Magarach Ampelographic Collection (village Vilino, Bakhchisarai district, Republic of Crimea): white - 'Kokur Belyi', 'Kokur Belyi 46-10-6', 'Solnechnaya Dolina 40', 'Solnechnaya Dolina 65', 'Makhrovatchic', 'Tsimlyanskii Belyi', 'Bulanyi Belyi', 'Pukhlyakovskii', 'Shampanchik Besserguenevskii'; and red - 'Demir Kara', 'Kefesiya', 'Capitan Yani Kara', 'Kokur Krasnyi', 'Chernyi Krymskii', 'Buryi', 'Tsimladar', 'Bezymyannyi'. The tirages from base wines of the 2018 cropping year were worked out in 2019 in accordance with the current technological instructions for production of sparkling wines using method of bottle champagnization and GOST 33311-2015. The post-tirage aging period consisted of 9 months. After carrying out the technological operations of remuage and degorgage in the finished sparkling wines, the physicochemical parameters were determined according to [16]. Foaming properties (maximum foam volume and time of foam destruction) were determined by the developed method (STO 01580301.015-2017) of bubbling air in a degassed wine sample poured in a measuring cylinder (capacity $-1 \mathrm{dm}^{3}$ ), using portable compressor and sprayer dipped into the bottom of the cylinder. The volume of the formed foam was visually assessed using a gradation scale of the cylinder, and the time of foam destruction was evaluated using a stopwatch. The qualitative and quantitative composition of organic acids was determined by the method of HPLC; the sample separation into individual substances was carried out on a Supelcogel $\mathrm{C} 610 \mathrm{H}$ column (Supelco ${ }^{\circledR}$, Sigma-Aldrich, USA) filled with a sorbent based on a sulfited divinyl-polystyrol (column size $300 \times 7.8$, sorbent granulating was no more than $10.0 \mu \mathrm{m}$ ), on a Shimadzu LC 20AD chromatograph (Japan) equipped with a spectrophotometric detector. An aqueous solution of ortho-phosphoric acid $\left(1 \mathrm{~g} / \mathrm{dm}^{3}\right)$ was used as an elution solvent. Mass concentration of organic acids in wine samples was determined according to the preliminary gradation of device in accordance with the standards of pure matter on spectrophotometric system detector at a wavelength of $210 \mathrm{~nm}$, taking into account the release time and spectral characteristics of all individual substances. The total content of carbon dioxide in sparkling wines was determined using the developed method (STO 01580301.016-2017), according to which the released from wine under the action of ultrasound $\mathrm{CO}_{2}$ was displacing the barrier fluid from graduated container. The volume of displaced barrier fluid corresponded to the volume of carbon dioxide contained in the bottle of sparkling wine. Calculations of the content of carbon dioxide bound forms were carried out according to the difference between the measured content of $\mathrm{CO}_{2}$ and the solubility of $\mathrm{CO}_{2}$ at a certain pressure and ethanol concentration [17]. Organoleptic assessment of sparkling wines was carried out in accordance with GOST 32051-2013 "Wine products. Methods of organoleptic analysis", ISO 5492:2008 "Sensory analysis Vocabulary", and ISO 11035:1994 "Sensory analysis - identification and selection of descriptors for establishing a sensory profile by a multidimensional approach". 
Organoleptic evaluation was provided according to a 10-point system (minimum allowed assessment score -8.8 points), as well as by quantitative expression of the contribution of individual descriptors to the combination of color, flavor and aroma of wines. The descriptors were picked in accordance with ISO 5492, ISO 11035 and [18].

The obtained entries were processed using methods of mathematical statistics and the Microsoft Excel software.

\section{Results and Discussion}

All sparkling wines obtained met the requirements of regulatory documents (GOST 333362015).

White sparkling wines by the content of phenolic substances can be conveniently divided into two groups. The first group included wines with mass concentration of the sum of phenolic substances $(\mathrm{SPhS})<350 \mathrm{mg} / \mathrm{dm}^{3}$ : 'Makhrovatchik', 'Tsimlyanskii Belyi', 'Bulanyi Belyi', 'Pukhlyakovskii', 'Solnechnaya Dolina 40'. The second group consisted of wines with mass concentration of the sum of phenolic substances $(\mathrm{SPhS})>350 \mathrm{mg} / \mathrm{dm}^{3}$ : 'Kokur Belyi', 'Kokur Belyi 46-10-6', 'Solnechnaya Dolina 65', 'Shampanchik Besserguenevskii'. Sparkling wines of the second group possessed golden tones of color with indicators of yellowness - more than 20, as more typical for white table aged wines [20]. Correlation (c) of yellowness parameter and mass concentration of polymeric forms of phenolic substances was 0.925 . In addition to the main parameters, we have studied the content of amino nitrogen as a part of substances with surface-active properties, involved in the formation of typical characteristics of sparkling wines. Mass concentration of amino nitrogen ranged from $112 \mathrm{mg} / \mathrm{dm}^{3}$ to $266 \mathrm{mg} / \mathrm{dm}^{3}$. The highest mass concentration of amino nitrogen was in the samples of sparkling wines prepared from the varieties 'Kokur Belyi 46-10-6' (266 mg/dm ${ }^{3}$ ) and 'Kokur Krasnyi' (266 mg/dm ${ }^{3}$ ), the lowest - in the sample of sparkling wine 'Pukhlyakovskii' $\left(112 \mathrm{mg} / \mathrm{dm}^{3}\right)$. Among the advanced parameters, the value of redox potential was determined, characterizing the state of environment and the redox reactions behavior. This parameter ranged from 186 ('Tsimlyanskii Belyi') - up to 220 ('Makhrovatchic') $\mathrm{mV}$, corresponding to the optimal values for sparkling wines. The content of aldehydes can serve as a criterion for oxidation degree of the samples. According to the research of G.G. Agabaliants, V.I. Nilov, E.N. Datunashvili, the tones of oxidation appear with an increase in the amount of aldehydes, formed resulting from oxidative deamination of amino acids with present oxygen. In this regard, we have studied the content of aldehydes in sparkling wines. In most of the samples, mass concentration of aldehydes was less than $100 \mathrm{mg} / \mathrm{dm}^{3}$. A higher mass concentration of aldehydes $(101$ $\mathrm{mg} / \mathrm{dm}^{3}$ ) was characteristic of the sample of sparkling wine, prepared from base wine of 'Solnechnaya Dolina 65' grape variety. According to the content of phenolic substances, red sparkling wines can also be conditionally divided into two groups. The first group with mass concentration of the sum of phenolic substances $(\mathrm{SPhS})<1000 \mathrm{mg} / \mathrm{dm}^{3}$ included: 'Kokur Krasnyi', 'Chernyi Krymskii', 'Buryi'. The second group with mass concentration of the sum of phenolic substances $(\mathrm{SPhS})>1000 \mathrm{mg} / \mathrm{dm}^{3}$ - 'Capitan Yani Kara', 'Tsimladar', 'Kefesiya', 'Demir Kara' and 'Bezymyannyi'. It should also be noted that in most samples, not including 'Kokur Krasnyi' and 'Bezymyannyi', the polymeric fraction of phenolic substances prevailed.

Shows, that the higher mass concentration of coloring substances was determined for sparkling wines of 'Tsimladar' $\left(116 \mathrm{mg} / \mathrm{dm}^{3}\right)$ and 'Bezymyannyi' $\left(99 \mathrm{mg} / \mathrm{dm}^{3}\right)$ grape varieties, and the lower one - from the varieties 'Chernyi Krymskii' $\left(33 \mathrm{mg} / \mathrm{dm}^{3}\right)$ and 'Kokur Krasnyi' (38 mg/dm ${ }^{3}$ ). The correlation of color intensity with mass concentration of coloring agents was 0.786 . The relationship between color intensity and concentration of monomeric forms of phenolic compounds $(r=0.580)$ was also established (Fig. 1). 


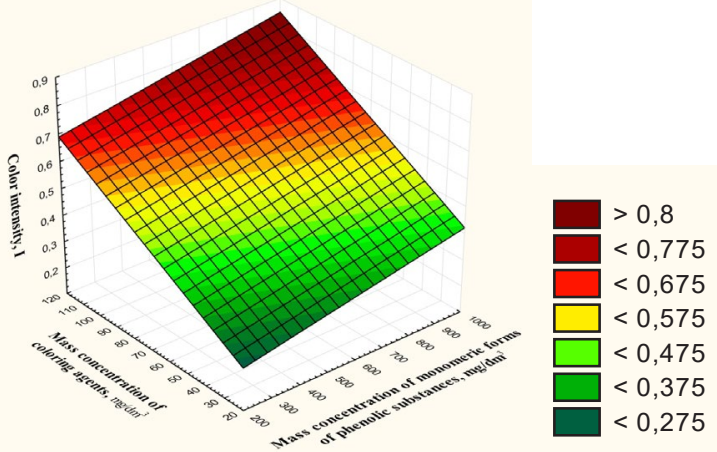

Fig. 1. Dependence of color intensity on mass concentration of monomeric forms of phenolic substances and coloring agents

The higher the content of monomeric forms of phenolic substances, in which coloring agents have dominating position, the higher the color intensity parameter. The established pattern may be used in the selection of technological parameters of grape processing in order to regulate monomeric and polymeric fractions of phenolic substances in the produced base wines or at the stage of blending to obtain the necessary color parameters of the final product.

At the same time, in all samples the color tone $(\mathrm{T})$ was less than 1 , indicating that the contribution of red pigments to the color prevailed over the contribution of yellow pigments.

According to the data obtained, mass concentration of titratable acids was lower than in the original base wines in all samples of sparkling wines. It was due to the partial precipitation of tartrates during the cold treatment of base wines, as well as due to the process of malolactic fermentation in some samples ('Solnechnaya Dolina 40', 'Demir Kara', 'Buryi', etc.). This is also evidenced by the low concentration of malic acid [19] and an increase in the concentration of lactic and amber acids, as well as an increase in the ratio of tartaric and malic acid. At the same time, it should be noted that in the samples of sparkling wines of 'Tsimladar' and 'Capitan Yani Kara' grape varieties, the concentration of acetic acid was slightly higher than in the rest of the samples, which affected the mass concentration of volatile acids.

According to the data obtained (Fig. 2), the balanced pressure of $\mathrm{CO}_{2}$ was within the normal range (300-560 $\mathrm{kPa})$.

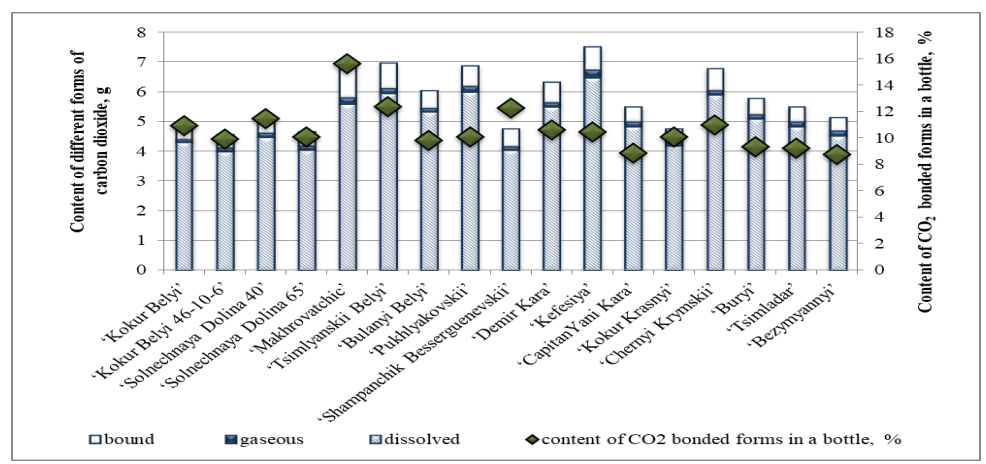

Fig. 2. Content of different forms of carbon dioxide in sparkling wines of local grape varieties.

All samples accumulated a sufficient amount of the bound $\mathrm{CO}_{2}$ (not less than $8 \%$ of the total content in a bottle). Most of the bound forms of $\mathrm{CO}_{2}$ were determined in the samples 
of white sparkling wines from the varieties 'Makhrovatchic' (15.6\%), 'Tsimlyanskii Belyi' $(12.3 \%)$ and 'Shampanchik Besserguenevskii' (12.3\%). The best foaming properties were registered in the samples: 'Makhrovatchic' (385 $\mathrm{cm}^{3}$ ) (white), 'Capitan Yani Kara' (620 $\left.\mathrm{cm}^{3}\right)$ and 'Bezymyannyi' $\left(540 \mathrm{~cm}^{3}\right)$ (red). It should be noted that maximum volume of foam correlates with mass concentration of polymeric forms of phenolic substances $(r=0.628)$.

As a result of the organoleptic analysis of sparkling wines, it was found that the samples were characterized by high quality with the manifestation of a complex aromatic complex with a wide range of directions depending on the grape variety: floral, fruit, fruit, spicy with various shades and a full harmonious taste. The aromatograms of some sparkling wines are shown in Fig. 3.

As a result of organoleptic analysis, golden tones in color were determined in a number of samples of white sparkling wines (with index of yellowness more than 20); red sparkling wines, conditionally placed into the first group in terms of the total amount of phenolic substances less than $1000 \mathrm{mg} / \mathrm{dm}^{3}$, were identified as dark-rose ('Kokur Krasnyi' and 'Chernyi Krymskii') or light red ('Buryi'). Among white sparkling wines, samples of the varieties 'Makhrovatchic' (8.97 points) and 'Tsimlyanskii Belyi' (8.97 points), among red ones - 'Kokur Krasnyi' (9.13 points), 'Tsimladar' (9.03 points), 'Kefesiya' (8.98 points) and 'Chernyi Krymskii' (8.96) gained higher tasting assessment.
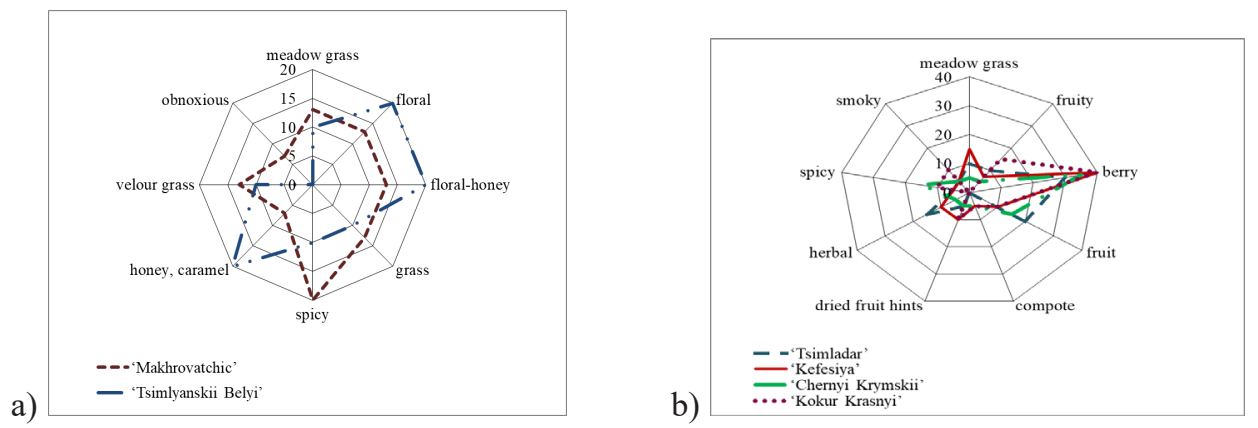

Fig. 3. Aromogram of white(a) and of red (b) sparkling wines sparkling wines.

\section{Conclusion}

Basing on the strength of physicochemical parameters among the studied sparkling wines made of local grapes, the most promising varieties are 'Makhrovatchic', 'Tsimlyanskii Belyi', 'Tsimladar', 'Kefesiya', 'Kokur Krasnyi' and 'Chernyi Krymskii'. They exhibit harmonious bouquet and flavor, optimal content of phenolic substances, good foaming properties and accumulate a sufficient amount of bound forms of carbon dioxide. The research on the possibility of producing high-quality sparkling wines from autochthonous grape varieties is planned to be continued.

\section{References}

1. D. Fracassetti, M. Gabrielli, O. Corona, A. Tirelli, Characterisation of Vernaccia Nera (Vitis vinifera L.) Grapes and Wine S. Afr. J. Enol. Vitic., 38, 1, 72-81(2017) http://dx.doi.org/10.21548/38-1-867

2. G. Merkouropoulos, I. Ganopoulos, A. Doulis, N. Nikolaou \& P. Mylona, OENO One, 50 (3) (2016) https://doi.org/10.20870/oeno-one.2016.50.3.1571

3. G.A. Samvelyan, A.G. Samvelyan, A.E. Manukyan, N.R. Simonyan, G.M. Avetisyan, Magarach, Viticulture and Winemaking, 23(1), 72-75 (2021) (in Russian) 
4. S. Pérez-Magariño, M. Ortega-Heras, L. Martínez-Lapuente, et al., Eur. Food Res. Technol. 236, 827-841 (2013) https://doi.org/10.1007/s00217-013-1934-9

5. D. Maghradze, A. Aslanishvili, I. Mdinaradze, D. Tkemaladze, L. Mekhuzla, et al., BIO Web of Conferences 12, 03003 (2019) https://doi.org/10.1051/bioconf/2 0191203003

6. A.M. Avidzba, V.A. Volinkin, V.V. Likhovsky, A.A. Polulyakh, L.P. Troshin, World ampelographical collection: NNIIViV "Magarach" and SKZNIISiV, Nauchnyj zhurnal KubGAU, 110 (06), 27 (2015) (in Russian) http://ej.kubagro.ru/2015/06/pdf/96.pdf

7. V.V. Taranenko, Viticulture and winemaking, 44, 14-16 (2014) (in Russian) https://www.elibrary.ru/download/elibrary_24369010_25954568.pdf

8. V.V. Likhovsky, V.A. Zlenko, V.A. Volinkin, N.P. Oleinikov, A.A. Polulyakh, I.A.Vasylyk, L.P. Troshin, Nauchnyj zhurnal KubGAU, 117(03), 14 (2016) (in Russian) http://ej.kubagro.ru/2016/03/pdf/44.pdf

9. V. Volynkin, A. Polulyakh, S.Levchenko, I. Vasylyk and V. Likhovskoi, Acta Hortic. 1259, 91-98 (2019) https://doi.org/10.17660/ActaHortic.2019.1259.16

10. S. Levchenko, I. Vasylyk, V. Volynkin, N. Rybachenko and A. Vasylyk, Acta Hortic. 1289, 261-268 (2020) https://doi.org/10.17660/ActaHortic.2020.1289.37

11. E. Ostroukhova, S. Levchenko, V. Likhovskoi, V. Volynkin, I. Peskova and I.Vasylyk. Acta Hortic. 1259, 105-114 (2019) https://doi.org/10.17660/ActaHortic.2019.1259.18

12. E. Ostroukhova, S. Levchenko, I. Vasylyk, V. Volynkin, N. Lutkova and V. Boyko E3S Web of Conferences 161, 01059 (2020) https://doi.org/10.1051/e3sconf/2 02016101059

13. A.S. Makarov, I.P. Lutkov, A.Ya. Yalanetskiy, N.A. Shmigelskaia, T.R. Shalimova, V.A. Maksimovskaia, V.V. Krechetova, D.Yu. Pogorelov, Magarach. Viticulture and Winemaking, 21(2), 147-152 (2019) (in Russian) https://elibrary.ru/download/eli brary_38188247_41958901.pdf

14. A.S. Makarov, I.P. Lutkov, N.A. Shmigelskaya, V.A. Maksimovskaya, Technological assessment of native white grape varieties in the system "grapes-base wine". Magarach. Viticulture and Winemaking. 22(3): 252-259 (2020) (in Russian). https://doi.org/10.35547/IM.2020.22.3.014

15. A.S. Makarov, I.P. Lutkov, N.A. Shmigelskaya, V.A. Maksimovskaya, G.V. Sivochoub, O.M. Beliakova, E.A. Slastya, Magarach. Viticulture and Winemaking, 22(1), 56-62 (2020) (in Russian) https://doi.org/10.35547/IM.2020.22.1.012

16. V.G. Gerzhikova, Metody tekhnohimicheskogo kontrolya v vinodelii, Simferopol. Tavrida pp. 304 (2009)

17. I.P. Lutkov, Vinogradarstvo i vinodelie, 47, 58-70 (2018) (in Russian)

18. B.L. Arroyo, R.P. Roberts, Procedia - Social and Behavioral Sciences, 198, 287-299 (2015) https://doi.org/10.1016/j.sbspro.2015.07.447

19. B.S. Chidi, F.F. Bauer, D. Rossouw, S. Afr. J. Enol. Vitic. 39, 2, (2018) http://dx.doi.org/10.21548/39-2-3164

20. N.S. Anikina, S.N. Cherviak, N.V. Gnilomedova, Methods for evaluating the color of wines. The review. Analitika and control [Analytics and control] 23, 2, 158-167 (2019) https://doi.org/10.15826/analitika.2019.23.2.003 